\title{
JURNAL ESESELATAN LINGEUNGAN

\section{HUBUNGAN IMUNISASI DENGAN KEJADIAN PENYAKIT INFEKSI SALURAN PERNAPASAN AKUT (ISPA) PADA BALITA DI WILAYAH KERJA PUSKESMAS POASIA KOTA KENDARI}

\section{The Relationship of Immunization and Acute Respiratory Infections (ARI) Disease Incidence in Toddlers in Working Area of Public Health Center of Poasia in Kendari City}

\author{
Ni Ketut Santi Ratna Puri ${ }^{1}$, Suhadi ${ }^{2^{*}}$, Fifi Nirmala $G^{3}$ \\ Jurusan Kesehatan Masyarakat, Fakultas Kesehatan Masyarakat, Universitas Halu Oleo \\ (santiratnap@gmail.com¹, suhaditsel77@yahoo.com²,fifinirmala87@gmail.com³)
}

\begin{tabular}{l}
\hline INFO ARTIKEL \\
\hline Diterima: \\
Juli 2020 \\
Dipublikasi: \\
Oktober 2020
\end{tabular}

Kata kunci:

Imunisasi, ISPA,

Puskesmas, Balita

\section{Keywords:}

Immunization, ISPA,

Puskesmas, Toddler

*Penulis Korespondensi

Alamat email:

suhaditsel@uho.ac.id

(Suhadi)

\begin{abstract}
Abstrak
Penyakit Infeksi Saluran Pernapasan Akut (ISPA) merupakan salah satu penyakit dengan angka kesakitan dan angka kematian yang cukup tinggi, sehingga dalam penanganannya diperlukan kesadaran yang tinggi baik dari masyarakat maupun petugas, terutama tentang pentingnya memperhatikan beberapa faktor yang menjadi pemicu terjadinya ISPA pada Balita. Beberapa faktor tersebut antara lain faktor imunisasi pada balita. Tujuan penelitian ini adalah untuk mengetahui hubungan imunisasi dengan kejadian ISPA pada balita di wilayah kerja Puskesmas Poasia. Metode penelitian ini adalah analitik observasional dengan rancangan cross-sectional study. Hasil Penelitian menunjukan bahwa ada hubungan yang signifikan antara kepadatan penghuni rumah dengan kejadian ISPA pada balita di Willayah Kerja Puskesmas Poasia ( $\mathrm{p}$ value $=0,001$ ). Kesimpulan penelitian ini yaitu ada hubungan anatara imunisasi dengan kejadian ISPA pada balita di Wilayah Kerja Puskesmas Poasia. Saran penelitian ini agar pemberian informasi juga harus dilengkapi dengan pemberian simulasi kepada masyarakat dalam bentuk lomba-lomba rumah sehat sehingga dapat memotivasi masyarakat untuk mewujudkan kondisi rumah sehat bagi setiap rumah.
\end{abstract}

Abstract
Acute Respiratory Infection (ARI) Disease is one of the diseases with a high
number of pain and mortality rates, so in handling it requires high awareness
from both the public and officers, especially about the importance of paying
attention to several factors that trigger the occurrence of ARI in toddlers.
Some of these factors include immunization factors in toddlers. The purpose of
this study was to find out the relationship of immunization with the incidence
of ARI in toddlers in the working area of Public Health Center of Poasia. This
research method was observational analytics with cross-sectional study design.
The results showed that there was a significant relationship between the
density of the occupants of the house and the incidence of ARI in toddlers in
Public Health Center of Poasia ( $p$-value = o.001). The conclusion of this study
was that there was a link immunization and the incidence of ISPA in toddlers in
the working area of Public Health Center of Poasia.




\section{JURNAL KESEHATAN LINGKUNGAN

\section{PENDAHULUAN}

Infeksi Saluran Pernapasan Akut adalah penyakit infeksi saluran pernapasan yang terjadi secara akut yang masih merupakan masalah kesehatan yang sangat serius terutama di negara-negara berkembang seperti Indonesia. ISPA merupakan penyakit yang menduduki kedudukan tertinggi di atas beberapa penyakit infeksi lainnya. Jumlah penderita ISPA Tahun 1996 menjadi penyebab kematian nomor satu di Amerika. Penggunaan antibiotik, membuat penyakit ini bisa dikontrol beberapa tahun kemudian (1).

Penyakit ISPA disebabkan oleh bakteri streptococcus pneumonia dan merupakan penyakit lama yang selalu ada dan bisa menular bila terjadi kontak langsung melalui mulut penderita. Namun demikian, tidak bisa menular langsung melalui udara yang terkontaminasi bakteri tersebut (2).

Infeksi Saluran Pernapasan Akut adalah proses infeksi akut berlangsung selama 14 hari, yang disebabkan oleh mikroorganisme dan menyerang salah satu bagian, dan atau lebih dari saluran napas, mulai dari hidung (saluran atas) hingga alveoli (saluran bawah), termasuk jaringan adneksanya, seperti sinus, rongga telinga tengah dan pleura. Gejala awal yang timbul biasanya berupa batuk pilek, yang kemudian diikuti dengan napas cepat dan napas sesak. Pada tingkat yang lebih berat terjadi kesukaran bernapas, tidak dapat minum, kejang, kesadaran menurun dan meninggal bila tidak segera diobati. Usia Balita adalah kelompok yang paling rentan dengan infeksi saluran pernapasan. Kenyataannya bahwa angka morbiditas dan mortalitas akibat ISPA, masih tinggi pada balita di negara berkembang (2).

World Health Organization (WHO) memperkirakan insiden infeksi ISPA di Negara berkembang dengan angka kematian balita di atas 40 per 1000 kelahiran hidup adalah $15 \%$ sampai $20 \%$ per tahun pada usia balita. Di Indonesia, ISPA selalu menempati urutan pertama penyebab kematian pada kelompok bayi dan balita. Berdasarkan prevalensi ISPA pada tahun 2016 di Indonesia telah mencapai $25 \%$ dengan rentang kejadian yaitu sekitar $17,5 \%$ sampai $41,4 \%$ dengan 16 provinsi di antaranya mempunyai prevalensi di angka nasional. Selain itu ISPA juga sering berada pada daftar 10 penyakit terbanyak di Rumah Sakit. Survey mortalitas yang dilakukan oleh Subdit ISPA pada tahun 2016 menempatkan ISPA sebagai penyebab kematian bayi terbesar di Indonesia dengan persentase 32,10\% dari seluruh kematian balita.

Penderita ISPA pada balita di Sulawesi Tenggara, sejak tahun 2016 hingga 2017, berturut-turut adalah 31.589 kasus (IR 0,03), 133.791 kasus (IR 0,06), sedangkan penderita ISPA pada balita di Kota Kendari dari tahun 2017 hingga 2018, berturut-turut adalah 41.261 kasus (IRo,16), dan 44.479 kasus (IR 0,17) (4).

Penyakit ISPA pada wilayah kerja Puskesmas Poasia, selalu menduduki urutan pertama pada daftar 10 besar penyakit. Penderita ISPA tahun 2017 sebanyak 3.676 kasus, 2384 (IR 0,11) diantaranya adalah balita. Tahun 2018 sebanyak 3.786 kasus, 2605 kasus $($ IR 0,12) diantaranya adalah balita. Kasus ISPA di Puskesmas Poasia pada tahun 2019 ditemukan sebanyak 4.848 kasus, 1.520 kasus

(IR 0,07) diantaranya adalah balita (5).

Jumlah penderita ISPA pada balita per kelurahan di wilayah kerja Pukesmas Poasia tahun 2019 antara lain: kelurahan Andonohu dengan jumlah penderita sebanyak 121 (IR $0,094)$, kelurahan Rahandouna dengan jumlah penderita sebanyak 224 (IR 0,074), kelurahan Wundumbatu dengan jumlah penderita sebanyak 189 (IR 0,068, kelurahan Anggoeya dengan jumlah penderita sebanyak195 (IR $0,052)$, kelurahan Matabubu dengan jumlah penderita sebanyak 239 (IR 0,048) (5).

Berdasarkan uraian di atas, penyakit ISPA merupakan salah satu penyakit dengan angka kesakitan dan angka kematian yang cukup tinggi, sehingga dalam penanganannya diperlukan kesadaran yang tinggi baik dari masyarakat maupun petugas, terutama tentang pentingnya memperhatikan beberapa faktor yang menjadi pemicu terjadinya ISPA pada Balita. Beberapa faktor tersebut antara lain faktor lingkungan seperti asap rumah tangga. Asap pembakaran rumah tangga yang tidak sempurna dari kayu bisa menyebabkan kanker paru-paru, kebutaan, jantung, bahkan pengaruh kognitif pada anak. Anak disebut juga menjadi korban karena biasanya mereka diajak oleh si ibu ketika memasak. Sebenarnya bukan kayu sebagai penyebab utama masalah kesehatan 


\section{JURNAL ISEDELATAN LINGEUNGAN

ini. Melainkan pembakarannya yang tidak sempurna. Asap yang melayang di sekitar si ibu dan anak, sama dengan bahaya rokok (6).

Selain itu faktor prilaku seperti kepadatan penghuni rumah juga dapat menjadi penyebab utama terjadinya ISPA. Faktor kepadatan penghuni rumah adalah paling dominan dan diduga sebagai faktor risiko terhadap timbulnya penyakit ISPA pada balita karena kepadatan buruk. Kepadatan mengenai kesehatan pada manusia yaitu meliputi perilaku kesehatan individu yaitu sikap dan kepadatan individu yang erat kaitannya dengan lingkungan rumah yaitu kepadatan penghuni rumah yang terlalu padat. Selain itu dan Imunisasi menjadi faktor penyebab terjadinya ISPA karena dengan tidak diberikan imunisasi secara lengkap kepada balita, maka daya tahan tubuh balita terhadap penyakit semakin berkurang karena fungsi imunisasi adalah meningkatkan kekebalan tubuh pada balita (7).

Berdasarkan hasil wawancara dengan 10 orang ibu balita dengan diagnosa ISPA yang berkunjung di Puskesmas Poasia, dimana 7 orang mengatakan bahwa kemungkinan besar anak mereka menderita ISPA disebabkan oleh asap rumah tangga karena masih menggunakan tungku untuk memasak sehingga banyak asap memenuhi rumah tangga dan terkadang masuk ke ruang rumah, selain itu mereka juga mengatakan bahwa terdapat kondisi rumah yang sempit menjadi penyebab terjadinya penyakit ISPA pada anak mereka, ditambah lagi anak mereka memiliki status imunisasi yang belum lengkap sehingga dugaan terjadinya ISPA disebabkan oleh ketiga hal tersebut.

Wawancara di atas didukung oleh penelitian yang dilakukan oleh Ike (2017) asap rumah tangga dan faktor prilaku seperti kepadatan rumah dalam rumah sangat berpengaruh karena semakin banyak penderita gangguan kesehatan akibat ataupun menghirup asap rokok (bagi perokok pasif) yang umumnya adalah perempuan dan anak-anak, sedangkan faktor pelayanan kesehatan seperti status imunisasi, ASI Ekslusif merupakan faktor yang dapat membantu mencegah terjadinya penyakit infeksi seperti gangguan pernapasan sehingga tidak mudah menjadi parah (8).
Penyakit ISPA dipengaruhi oleh kualitas udara dalam rumah. Berdasarkan jurnal Chahaya dan Nurmaini (2015) di Desa Deli Serdang yang menunjukkan bahwa terdapat pengaruh paparan asap dengan kejadian ISPA pada balita (9). Penelitian Aisyaroh (2016) ada pengaruh perilaku orang tua dan penghuni rumah yang tinggal satu rumah dengan kejadian ISPA pada balita (10).

\section{METODE}

Jenis penelitian yang dilakukan adalah observasional dengan pendekatan crosssectional study, yaitu untuk mempelajari hubungan faktor-faktor risiko dengan efek, dengan cara pendekatan observasi atau pengumpulan data sekaligus pada suatu saat, artinya tiap variabel penelitian hanya diobservasi sekali saja dan diamati pada waktu yang sama.

\section{HASIL}

Tabel 1. Distribusi Kejadian ISPA pada Balita di Wilayah Kerja Puskesmas Poasia Kota Kendari

\begin{tabular}{ccc}
\hline \multirow{2}{*}{ Kejadian ISPA } & \multicolumn{2}{c}{ Jumlah } \\
\cline { 2 - 3 } & $\mathbf{n}$ & $\%$ \\
\hline Menderita & 56 & 60,9 \\
\hline Tidak Menderita & 36 & 39,1 \\
\hline Total & $\mathbf{9 2}$ & $\mathbf{1 0 0}$ \\
\hline
\end{tabular}

Tabel. 1 menunjukkan bahwa kejadian ISPA pada balita dengan kategori penderita sebanyak 56 balita (60,9\%), lebih banyak kategori tidak menderita, yaitu sebanyak 36 balita (39,1\%).

Tabel 2. Distribusi Imunisasi Tentang ISPA di Wilayah Kerja Puskesmas Poasia Kota Kendari Propinsi Sulawesi Tenggara

\begin{tabular}{ccc}
\hline \multirow{2}{*}{$\begin{array}{c}\text { Imunisasi Tentang } \\
\text { ISPA }\end{array}$} & $\mathbf{n}$ & Jumlah \\
\cline { 2 - 3 } Lengkap & 39 & 42,4 \\
\hline Tidak Lengkap & 53 & 57,6 \\
\hline Total & $\mathbf{9 2}$ & $\mathbf{1 0 0}$ \\
\hline
\end{tabular}

Tabel. 2 menunjukkan balita dengan status imunisasi tidak lengkap diperoleh sebanyak sebanyak 53 responden (57,6\%), sedangkan dengan status imunisasi lengkap sebanyak 39 responden (42,4\%). 


\section{JURNAL KESEHATAN LINGKUNGAN

Tabel 3. Hubungan Imunisasi tentang ISPA dengan Kejadian ISPA pada Balita

\begin{tabular}{|c|c|c|c|c|c|c|c|}
\hline \multirow{3}{*}{$\begin{array}{l}\text { Status } \\
\text { Imunisasi }\end{array}$} & \multicolumn{4}{|c|}{ Kejadian ISPA Balita } & \multirow{2}{*}{\multicolumn{2}{|c|}{ Jumlah }} & \multirow{3}{*}{ p-value } \\
\hline & \multicolumn{2}{|c|}{ Penderita } & \multicolumn{2}{|c|}{$\begin{array}{c}\text { Tidak } \\
\text { Menderita }\end{array}$} & & & \\
\hline & $\mathbf{n}$ & $\%$ & $\mathbf{n}$ & $\%$ & $\mathbf{n}$ & $\%$ & \\
\hline Lengkap & 16 & 17,4 & 23 & 25 & 39 & 42,39 & \\
\hline $\begin{array}{c}\text { Tidak } \\
\text { Lengkap }\end{array}$ & 40 & 43,5 & 13 & 14,1 & 53 & 57,61 & 0,001 \\
\hline Total & 56 & 60,9 & 36 & 39,1 & 92 & 100 & \\
\hline
\end{tabular}

Tabel 3 di atas menunjukkan bahwa dari 39 balita (42,39\%) dengan status imunisasi lengkap terdapat 16 balita $(17,4 \%)$ menderita ISPA dan sebanyak 23 balita (25\%) tidak menderita ISPA. Sedangkan dari 53 balita $(57,61 \%)$ dengan imunisasi yang tidak lengkap terdapat 40 balita $(43,5 \%)$ menderita ISPA dan 13 balita (14,1\%) tidak menderita ISPA. Berdasarkan hasil pengujian statistik menunjukkan adanya hubungan dengan nilai probabilitas $(p$-value $)=0,001<a(0,05)$ pada $\mathrm{df}=1$.

\section{PEMBAHASAN}

Hubungan Status Imunisasi Tentang ISPA dengan Kejadian ISPA pada Balita

Infeksi saluran pernapasan akut merupakan salah satu penyakit yang dapat dicegah dengan imunisasi. Salah satu faktor penyebab ISPA adalah status imunisasi pada balita. ISPA berasal dari jenis penyakit yang berkembang dari penyakit yang dapat dicegah seperti difteri, pertusis, dan campak, maka peningkatan cakupan imunisasi akan berperan besar dalam upaya pemberantasan ISPA (11). Cara yang terbukti paling efektif saat ini adalah dengan pemberian imunisasi campak, pemberian imunisasi lengkap sebelum anak mencapai usia 1 tahun, anak akan terlindung dari beberapa penyebab yang paling utama dari infeksi pernafasan termasuk batuk rejan, difteri, tuberkulosa dan campak. Penderita difteri, pertusis apabila tidak mendapat pertolongan yang memadai akan berakibat fatal. Dengan pemberian imunisasi lengkap dapat mencegah kematian ISPA yang diakibatkan oleh komplikasi penyakit campak dan pertusis (2).

Penelitian ini menunjukkan bahwa status ketidaklengkapan imunisasi dapat menjadi faktor risiko kejadian ISPA. Berdasarkan hasil temuan peneliti dari 92 ibu balita yang dijadikan responden penelitian didapatkan 53 balita (57,61\%) diantaranya masih memiliki status imunisasi tidak lengkap. Keadaan ini tentunya memberi gambaran akan masih rendahnya kemampuan masyarakat dalam upaya perwujudan hidup sehat bagi balitanya sehingga dapat mencegah terjadinya ISPA termasuk upaya penanganan balita yang menderita ISPA.

Berdasarkan hasil penelitian dapat dilihat bahwa status kelengkapan imunisasi mempunyai peran yang sangat besar dalam pemeliharaan kesehatan tubuh balita dalam mencegah penyakit infeksi khususnya ISPA pada balita. Sehingga dapat disimpulkan bahwa kelengkapan imunisasi mempengaruhi kejadian ISPA pada balita.

Sebagian besar kematian ISPA berasal dari jenis ISPA yang berkembang dari penyakit yang dapat dicegah dengan imunisasi seperti difteri, pertusis, dan campak, maka cakupan peningkatan imunisasi akan berperan besar dalam upaya pemberantasan ISPA. Meskipun masih terdapat sebagian balita yang memiliki imunisasi lengkap namun tetap mengalami ISPA yaitu sebanyak 16 balita (17,4\%). Hal ini bisa dikarenakan adanya balita yang memiliki status gizi kurang dan riwayat BBLR serta faktor-faktor lain yang menjadi penyebab terjadinya ISPA yang tidak ditelusuri dalam penelitian ini sehingga menjadi keterbatasan dalam penelitian ini.

Penelitian ini sejalan dengan pernyataan Wantania (2018) terdapat banyak faktor yang mendasari perjalanan penyakit ISPA pada anak seperti usia, jenis kelamin, status gizi, pemberian ASI, BBLR, imunisasi, pendidikan orang tua, status sosial ekonomi, penggunaan fasilitas kesehatan dan lingkungan (12). Menurut Maryunani (2015) untuk mengurangi faktor yang meningkatkan mortalitas ISPA, diupayakan imunisasi lengkap. Bayi dan balita yang mempunyai status imunisasi lengkap bila menderita ISPA dapat diharapkan perkembangan penyakitnya tidak akan menjadi lebih berat (13).

Hasil penelitian yang menunjukkan bahwa dari 53 balita $(57,61 \%)$ dengan status imunisasi tidak lengkap lebih banyak mengalami penyakit ISPA yaitu sebanyak 40 balita (43,5\%), dan sebanyak 13 balita (14,1\%) tidak mengalami penyakit ISPA. Sementara itu status imunisasi dengan kategori lengkap 


\section{JURNAL ESESELATAN LINGEUNGAN

sebanyak 39 balita (42,39\%), terdapat sebanyak 16 balita $(17,4 \%)$ mengalami penyakit ISPA dan sebanyak 23 balita (25\%) tidak mengalami penyakit ISPA. Berdasarkan hasil pengujian statistik menunjukkan adanya hubungan dengan nilai probabilitas ( $\mathrm{p}$ value $)=$ $0,001<$ nilai alpha $(0,05)$ pada $\mathrm{df}=1$.

Hasil penelitian menunjukkan bahwa distribusi kejadian ISPA dilihat dari pendidikan ibu balita, terdapat sebanyak 6 orang mengalami penyakit ISPA, pendidikan SMP sebanyak 23 orang mengalami penyakit ISPA, pendidikan SMA sebanyak 21 orang mengalami penyakit ISPA, pendidikan Diploma sebayak sebanyak 5 orang mengalami penyakit ISPA, dan pendidikan strata I sebanyak 1 orang mengalami penyakit ISPA sehingga total kejadian ISPA secara keseluruhan sebanyak 56 orang. Dari hasil penelitian ini dapat diketahui bahwa yang paling banyak terkena ISPA pada balita adalah ibu dengan pendidikan SMP yaitu sebanyak 23 balita.

Penelitian ini sejalan dengan penelitian yang dilakukan oleh Astuti (2007) di Puskesmas Barandasi Kota Maros yang menyatakan bahwa status imunisasi akan membantu ibu balita mewujudkan pola hidup sehat kepada anak balitanya yang terhindar dari penyebab ISPA termasuk untuk menunjang tindakan yang dapat dilaksanakan ibu sehubungan dengan adanya kejadian ISPA pada balita (14).

Hasil penelitian juga menunjukkan bahwa distribusi kejadian ISPA dilihat dari kelompok umur balita terdapat usia balita 6-12 bulan sebanyak 14 balita mengalami penyakit ISPA, umur 13-24 bulan sebanyak 9 balita mengalami penyakit ISPA, umur 25-36 bulan sebanyak 15 balita mengalami penyakit ISPA, umur 37-48 sebayak 10 balita mengalami penyakit ISPA, dan umur 49-60 bulan sebanyak 8 balita mengalami penyakit ISPA, sehingga total kejadian ISPA secara keseluruhan sebanyak 56 orang balita. Dari hasil penelitian ini dapat diketahui bahwa yang paling banyak terdistribusi mengalami penyakit ISPA pada balita adalah balita dengan umur 25-36 bulan yaitu sebanyak 15 balita.

\section{KESIMPULAN}

Kesimpulan dalam penelitian ini menujukkan bahwa ada hubungan antara status imunisasi dengan kejadian ISPA pada balita di wilayah kerja Puskesmas Poasia.

\section{SARAN}

Pemberian informasi juga harus dilengkapi dengan pemberian stimulasi kepada masyarakat dalam bentuk lombalomba rumah sehat sehingga dapat memotivasi masyarakat untuk mewujudkan kondisi rumah sehat bagi setiap rumah.

\section{DAFTAR PUSTAKA}

1. Husnul. (2016), Makna Penyuluhan dan Transformasi Perilaku Manusia. Jurnal Penyuluhan. 16 (1), 7-10.

2. Kemenkes RI, (2015). Klasifikasi Penyakit. Departemen Kesehatan Republik Indonesia. Peraturan Menteri Kesehatan. Jakarta.

3. Dines Kesehatan Provinsi Sulawesi Tenggara. (2017)Profil Kesehatan Provinsi Sulawesi Tenggara, Kendari: Dinkes.

4. Dines Kesehatan Kabupaten Kota. (2018) Laporan Tahunan Penyakit ISPA Dinas Kesehatan Kota Kendari. Kendari: DinKes.

5. Puskesmas Poasia. (2019)Laporan Bulanan Penyakit Puskesmas Poasia. Kota Kendari.

6. Kirby. (2017) Imun and ISPA Education Programs: Their Impcat on Imunisation. Journal of Publich Heatlh. 3 (2), 4-7.

7. Notoatmodjo S. (2007). Metode Penelitian Kesehatan. Jakarta: Rineka Cipta.

8. Ike, S. (2017) Hubungan antara Paparan Asap Rumah tangga, KepadatanPenghuniRumah, Imunisasi, Pemberian ASI Esklusif, dan BBLR Terhadap Kejadian ISPA di Universitas Amangkurat. Jurnal Universitas Amangkurat. 10 (3), 3-9.

9. Chahaya \& Nurmaini. (2012). Faktor Risiko Kejadian Infeksi Saluran Pernapasan Akut Pada Anak Balita di Deli Serdang. Tamalate. Makassar.

10. Aisyaroh N, (2016). Imunisasi dan Upaya Terbaik Mencegah Penyakit pada Balita. Universitas Sultan Agung. Jurnal Penyuluhan 12 (7), 3-8.

11. Anik. (2010). Faktor Penyebab ISPA pada Balita. Jogjakarta: Nuha Medika. 


\section{JURNAL KESEHATAN LINGKUNGAN UNIV. HALU OLEO (JKL - UHO)}

12. Wantania JM, Naning R, Wahani A. (2018). Infeksi Saluran Pernapsan Akut. Buku Ajar Respirologi Anak 1st ed. Jakarta. Ikatan Dokter Anak Indonesia.

13. Marynani A. (2015). Ilmu Kesehatana Anak dalam Kebidanan. Jakarta: trans info media.

14. Astuti, (2007). Faktor-faktor yang berhubungan dengan kejadian ISPA di Puskesmas Barandasi Kota Maros, Jurnal Kesmas Tamalate. Sulsel. 3 (2), 